\title{
Microbiology
}

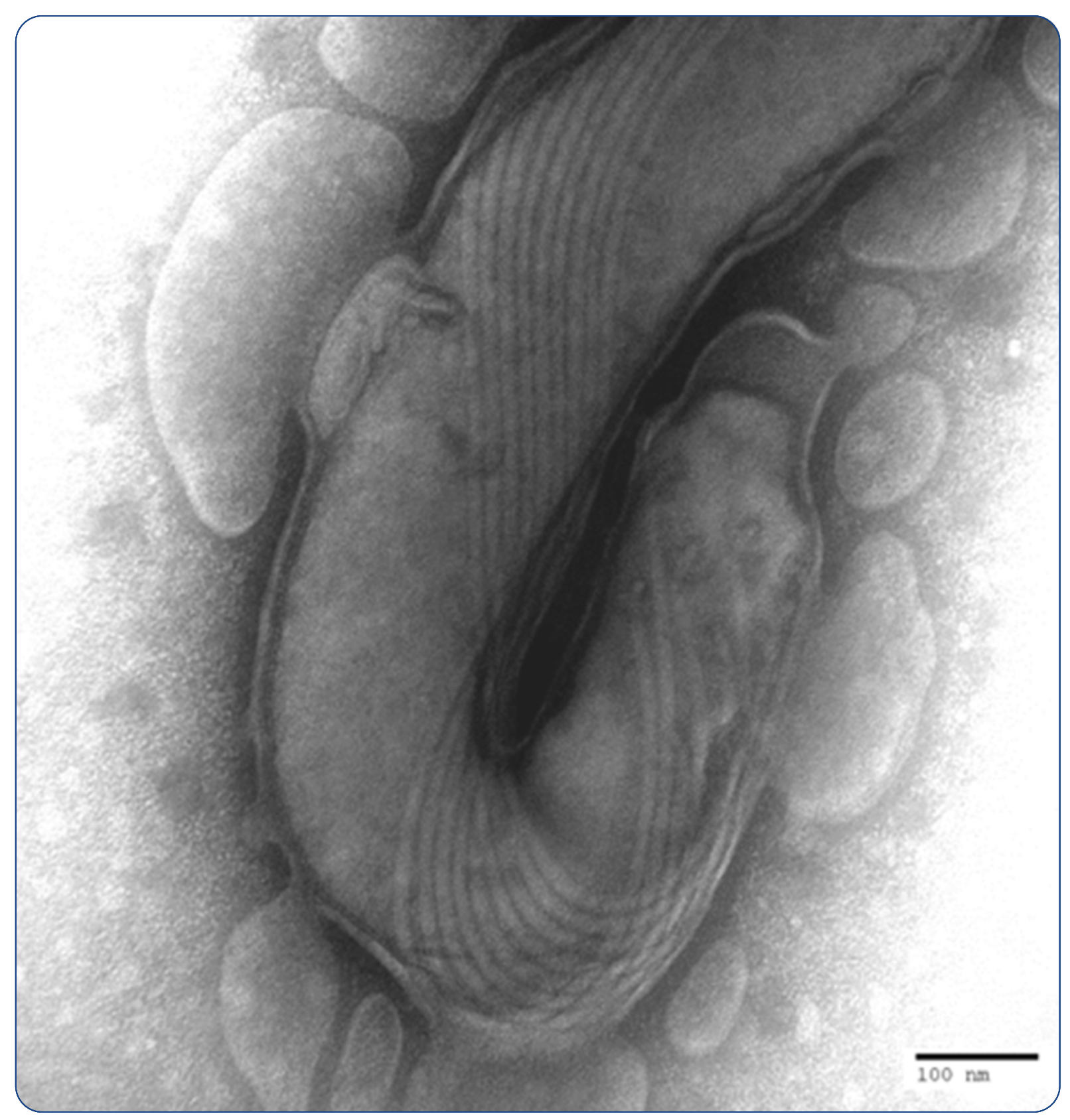

\section{Biochemical and molecular characterization of Treponema phagedenis-like spirochetes isolated from a bovine digital dermatitis lesion}

Wilson-Welder et al. 


\title{
Biochemical and molecular characterization of Treponema phagedenis-like spirochetes isolated from a bovine digital dermatitis lesion
}

\author{
Jennifer H Wilson-Welder ${ }^{1,3^{*}}$, Margaret K Elliott ${ }^{1}$, Richard L Zuerner ${ }^{1,3}$, Darrell O Bayles ${ }^{1}$, David P Alt ${ }^{1}$ \\ and Thad B Stanton ${ }^{2}$
}

\begin{abstract}
Background: Bovine papillomatous digital dermatitis (DD) is the leading cause of lameness in dairy cattle and represents a serious welfare and economic burden. Found primarily in high production dairy cattle worldwide, DD is characterized by the development of an often painful red, raw ulcerative or papillomatous lesion frequently located near the interdigital cleft and above the bulbs of the heel. While the exact etiology is unknown, several spirochete species have been isolated from lesion material. Four isolates of Treponema phagedenis-like spirochetes were isolated from dairy cows in lowa. Given the distinct differences in host, environmental niche, and disease association, a closer analysis of phenotypic characteristics, growth characteristics, and genomic sequences of $T$. phagedenis, a human genitalia commensal, and the lowa DD isolates was undertaken.

Results: Phenotypically, these isolates range from 8.0 to $9.7 \mu \mathrm{m}$ in length with 6-8 flagella on each end. These isolates, like T. phagedenis, are strictly anaerobic, require serum and volatile fatty acids for growth, and are capable of fermenting fructose, mannitol, pectin, mannose, ribose, maltose, and glucose. Major glucose fermentation products produced are formate, acetate, and butyrate. Further study was conducted with a single isolate, 4A, showing an optimal growth pH of 7.0 (range of 6-8.5) and an optimal growth temperature of $40^{\circ} \mathrm{C}$ (range of $29^{\circ} \mathrm{C}-43^{\circ} \mathrm{C}$ ). Comparison of partial genomic contigs of isolate $4 \mathrm{~A}$ and contigs of $T$. phagedenis F0421 revealed $>95 \%$ amino acid sequence identity with amino acid sequence of 4A. In silico DNA-DNA whole genome hybridization and BLAT analysis indicated a DDH estimate of $>80 \%$ between isolate $4 \mathrm{~A}$ and T. phagedenis F0421, and estimates of $52.5 \%$ or less when compared to the fully sequenced genomes of other treponeme species.
\end{abstract}

Conclusion: Using both physiological, biochemical and genomic analysis, there is a lack of evidence for difference between T. phagedenis and isolate 4A. The description of Treponema phagedenis should be expanded from human genital skin commensal to include being an inhabitant within DD lesions in cattle.

Keywords: Bovine digital dermatitis, Treponema, Spirochete, Bacterial growth, Genomic comparison

\section{Background}

Bovine papillomatous digital dermatitis (DD) is the primary cause of lameness in dairy cattle and is a growing concern to the beef industry [1]. Lameness attributed to DD costs the producer \$125-216/occurrence (treatment, lost productivity) representing a serious financial burden

\footnotetext{
* Correspondence: jennifer.wilson-welder@ars.usda.gov

'Infectious Bacterial Diseases Research Unit, National Animal Disease Center,

Ames, lowa 50010, USA

${ }^{3}$ Mailing address: USDA, ARS, National Animal Disease Center, $1920 \mathrm{~N}$.

Dayton Ave, P.O. Box 70, Ames, IA 50010, USA

Full list of author information is available at the end of the article
}

to the farmer, especially when considering that a large percentage of the herd may be affected [2,3]. Typical DD lesions are characterized by a rough, raw raised area most often occurring on the hind limb between the heel bulb and dewclaw and may develop keratinaceous hairlike projections. Lesions appear painful and are prone to bleeding when probed. Lesions generally do not heal spontaneously and may progress to severe lameness. Efficacious vaccines have so far been elusive $[4,5]$. Despite treatment and attempts at control, reoccurrence of lesions both on the same hoof/cow and within the 
herd remains high [6]. Additionally, the welfare issue of maintaining food-producing animals in a healthy, painfree state cannot be ignored [7].

Several Treponema species have been identified in tissue biopsies from DD lesions by in situ hybridization, immunohistochemistry and 16S rDNA sequence homology [8-12]. Routinely, treponemes are found at the leading edge of lesions, deep within the tissue. Taking into account the spatial distribution of treponemes within the lesion and the robust immune response directed toward them [13-15], it is thought that these organisms may be key factors in DD lesion development.

The goal of this study was to further characterize and compare laboratory growth characteristics, morphology, enzyme profiles, and draft genomic sequences of the $T$. phagedenis DD isolates, originally described by Trott et al. [14]. While these isolates share greater than 98\% $16 \mathrm{~S}$ rDNA homology with $T$. phagedenis, with each other, and with isolates from dairy herds in California [10], the United Kingdom [16], and Sweden [17], antigenic variation and serological reactivity differ [13]. Previous studies have focused on $16 \mathrm{~S}$ rDNA analysis for phylogenetic relatedness of Treponema isolates. Given differences in environmental niche and host species between DD isolates and T. phagedenis type strains, we sought to compare the physical appearance, growth rate, biochemical substrates, and draft genomes. Results of these studies and genome-wide comparisons indicate that $T$. phagedenis-like isolates from DD lesions of cattle are nearly identical to $T$. phagedenis, suggesting an expansion of environmental niches occupied by this bacterium. We propose the description of $T$. phagedenis be expanded to include both human commensal and putative bovine pathogen.

\section{Results}

Morphology

Morphological characteristics were determined by phase contrast, dark field, and electron microscopy. Cells were grown in OTI and visualized directly from log-phase culture by phase contrast and dark field microscopy. Cells exhibited typical helical morphology with a slight flattening of the pitch at one or both ends of the cell. Both rotating and translational motility was observed under dark field microscopy. As determined by electron microscopy, cell dimensions of isolates $1 \mathrm{~A}, 3 \mathrm{~A}, 4 \mathrm{~A}$ and $5 \mathrm{~B}$ varied from 8 to $9.7 \mu \mathrm{m}$ in length and 0.3 to $0.35 \mu \mathrm{m}$ in width, with 7 to 9 flagella attached on terminal ends with 7-14-7, 8-16-8 or 9-18-9 arrangements (Figure 1, Table 1).

\section{API ZYM profile}

The enzyme activity profiles of the four Iowa isolates and the reference treponeme species were determined

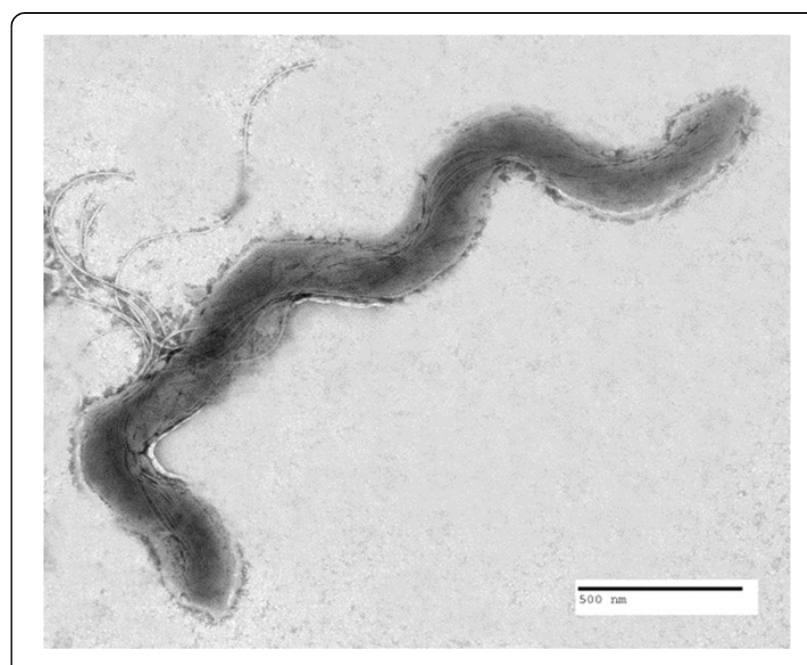

Figure 1 Negative stained electron photomicrograph of isolate $1 \mathrm{~A}$ at $13000 \mathrm{x}$ magnification showing exposed flagella and insertion disks. Scale bar equal $500 \mathrm{~nm}$.

using the API ZYM system. Table 2 shows a comparison of the enzyme activities of these isolates with $T$. phagedenis, T. denticola, and other treponeme isolates. The $T$. phagedenis-like DD isolates shared positive reaction for: alkaline phosphatase, $\mathrm{C}_{4}$ esterase, $\mathrm{C}_{8}$ esterase lipase, acid phosphatase, naptholphosphohydrolase, $\beta$-galactosidase, and $\mathrm{N}$-acetyl- $\beta$-glucosaminidase. These results matched the T. phagedenis biovar Kazan reactivity profile, except that Kazan additionally tested positive for leucine arylamidase activity. The two biovars of T. phagedenis (Kazan and Reiter) differed in 6 of the API ZYM tests from each other and are known to differ in enzymatic activity [18]. In contrast, $T$. denticola differed in six different enzymatic reactions from the Iowa DD isolates. Assay variability is clearly demonstrated as in this study $T$. denticola showed positive reactivity for $\mathrm{C}_{8}$ esterase lipase, acid phosphatase, naptholphosphohydrolase, $\alpha$-galactosidase, and $\alpha$-glucosidase where the same strain published elsewhere was negative for these 5 enzymes but positive for chymotrypsin [19]. Although assay subjectivity and variations in methodology make cross-laboratory comparisons difficult, the API-ZYM profile for Iowa DD isolates closely match the published profile for $T$. phagedenis and $T$. brennaborense as well as several other $T$.

Table 1 Size and flagella number for lowa isolates as determined by electron microscopy

\begin{tabular}{lccccc}
\hline & $\begin{array}{c}\text { Isolate } \\
\mathbf{1 A}\end{array}$ & $\begin{array}{c}\text { Isolate } \\
\mathbf{3 A}\end{array}$ & $\begin{array}{c}\text { Isolate } \\
\mathbf{4 A}\end{array}$ & $\begin{array}{c}\text { Isolate } \\
\text { 5B }\end{array}$ & $\begin{array}{c}\text { T. phagedenis } \\
\text { Kazan }\end{array}$ \\
\hline $\begin{array}{l}\text { Length }(\mu \mathrm{m}) \pm \\
\text { StdDev }\end{array}$ & $8.0 \pm 0.8$ & $8.7 \pm 1.3$ & $9.7 \pm 2.6$ & $9.4 \pm 0.9$ & $10.4 \pm 0.9$ \\
$\begin{array}{l}\text { Flagella number } \\
(\text { single end) } \pm\end{array}$ & $7.3 \pm 1.2$ & $7.3 \pm 0.5$ & $8.7 \pm 0.9$ & $6.6 \pm 0.9$ & $6.9 \pm 1.2$ \\
StdDev & & & & & \\
\hline
\end{tabular}


Table 2 Comparison of API-ZYM substrate reactivity profiles of lowa isolates against other DD isolates and known Treponema strains

\begin{tabular}{|c|c|c|c|c|c|c|c|c|c|c|c|c|c|c|c|c|c|c|c|}
\hline & 1 & 2 & 3 & 4 & 5 & 6 & 7 & 8 & 9 & 10 & 11 & 12 & 13 & 14 & 15 & 16 & 17 & 18 & 19 \\
\hline lowa Isolates $1 \mathrm{~A}, 3 \mathrm{~A}, 4 \mathrm{~A} \& 5 \mathrm{~B}^{*}$ & + & + & + & - & - & - & - & - & - & + & + & - & + & - & - & - & + & - & - \\
\hline T. phagedenis Kazan* & + & + & + & - & + & - & - & - & - & + & + & - & + & - & - & - & + & - & - \\
\hline T. phagedenis Reiter§ & - & - & - & - & - & - & - & - & - & + & - & - & + & + & - & - & + & - & - \\
\hline T. denticola (ATCC 35405)* & - & + & + & - & - & - & - & + & - & + & + & + & - & - & + & - & - & - & - \\
\hline T. denticola (ATCC 35405) \# & - & + & - & - & - & - & - & + & + & - & - & - & - & - & - & - & - & - & - \\
\hline T. brennaborense (isolate DD5/3)§ & + & + & + & - & - & - & - & - & - & + & + & - & + & - & + & - & + & - & - \\
\hline T. maltophilum(ATCC 51939)§ & + & + & + & - & - & - & - & - & - & + & + & + & - & - & + & - & - & - & + \\
\hline Bovine isolate V1 \& others 9 & + & + & + & - & $-^{* *}$ & - & - & - & - & + & + & - & + & + & - & - & + & - & - \\
\hline Isolates from UK cattle, Group 1 (x5)† & + & + & + & - & + & - & - & - & - & + & - & - & - & - & - & - & - & - & - \\
\hline Isolates from UK cattle, Group 2 (x14)† & + & + & + & - & - & - & - & - & - & + & + & - & + & + & - & - & + & - & + \\
\hline Isolates from UK cattle, Group $3(x 4) \dagger$ & - & + & + & - & - & - & - & + & + & - & - & - & - & - & - & - & - & - & - \\
\hline CA Bovine isolates $(x 7) \neq$ & + & + & + & - & - & - & - & - & - & + & + & - & + & + & - & - & + & - & - \\
\hline Bovine isolate1-9185MED $\neq$ & + & + & + & - & - & - & - & + & + & + & + & - & - & - & - & - & - & - & - \\
\hline
\end{tabular}

Enzymes: 1, alkaline phosphatase; $2, C_{4}$ esterase; $3, C_{8}$ esterase lipase; $4 C_{14}$ lipase; 5 leucine arylamidase; 6 valine arylamidase; 7 cystine arylamidase; 8 , trypsin; 9, chymotrypsin; 10 , acid phosphatase; 11 , naphtholphosphohydrolase; 12 , a-galactosidase; 13 , $\beta$-galactosidase; 14 , $\beta$-glucuronidase; 15 , a-glucosidase; 16 , $\beta$-glucosidase; 17, N-acetyl- $\beta$-glucosaminidase; 18, a-mannosidase; 19, a-fucosidase.

${ }^{*}$ As determined in this study, ${ }^{* *}$ Isolate T 551B only + .

§ Schrank et al. [27], ‡ Walker et al. [11], १ Pringle et al. [17], \# Wyss et al. [19], † Evans et al. [16].

phagedenis-like DD isolates including Swedish Bovine isolate V1 [17], isolates from UK cattle Group 2 ( $T$. phagedenis-clustering) [16], and several California Bovine isolates [20].

\section{Volatile fatty acid production}

Comparison of metabolite or volatile fatty acid (VFA) production was measured by mass spectrometry of clarified spent medium. Uninoculated medium was incubated similarly to inoculated media and measured for background VFA content. The Iowa DD isolates produced formic, acetic and butyric acids, as did $T$. phagedenis biovar Kazan. In contrast, $T$. denticola produced large amounts of acetic and lactic acid but no measurable amount of any other VFA (data not shown).

\section{Hydrogen sulfide production}

All isolates and reference species produced copious amounts of hydrogen sulfide as measured by lead acetate paper suspended above the actively growing culture.

\section{Substrate utilization and growth conditions}

All four of the original Iowa DD isolates shared enzymatic similarity, 16SrRNA gene sequence similarity, and were isolated from the same herd. Consequently, further examination of growth characteristics and nutrient utilization were carried out using isolate 4A. Growth of isolate 4A did not occur in OTI without the addition of bovine rumen fluid or in the absence of volatile fatty acids in BMV (data not shown). Bovine serum was required for growth in both media types. In contrast to $T$. vincentii and $T$. denticola, $T$. phagedenis and isolate 4A required serum in addition to VFA and complex amino acids for growth [21]. Nutrient utilization was determined for isolate 4A cells grown in BMV medium. Isolate $4 \mathrm{~A}$ grew in the absence of heart infusion broth but growth was restricted in the absence of polypeptone or yeast extract, suggesting an amino acid requirement. Enhanced growth (resulting in an increase in O.D. $<0.1$ above that seen when isolate $4 \mathrm{~A}$ was grown in BMV without carbohydrate) was observed using fructose, glucose, maltose, mannitol, mannose, pectin, ribose and soluble starch as carbohydrate source, whereas no enhancement of growth was observed for arabinose, cellobiose, galactose, lactose, sucrose, trehalose or xylose. These results are summarized and compared to two other Treponema species (Table 3). Optimal growth temperature for isolate $4 \mathrm{~A}$ is $40^{\circ} \mathrm{C}$ with a range of $29-42^{\circ} \mathrm{C}$. Cells in OTI exposed to lower temperatures (down to $4^{\circ} \mathrm{C}$ ) do not grow but remain viable for an extended period of time and will resume growth upon incubation in the optimal temperature range (data not shown). Optimal $\mathrm{pH}$ for growth of isolate $4 \mathrm{~A}$ is $\mathrm{pH} 7.4$ with a range of 6.5-8.0. The general description, temperature, $\mathrm{pH}$ range and serum requirement for growth of isolate $4 \mathrm{~A}$ match those given for Treponema phagedenis in Bergey's Manual of Systematic Bacteriology [18]. Mean generation time in OTI was 4 hours with a maximal density of $10^{9}$ cells $/ \mathrm{ml}$ in 96 hours (Additional file 1: Figure S1). Mean generation time in BMV was slightly longer, at 6.8 hours and reaching lower maximal density of $10^{8}$ cells $/ \mathrm{ml}$ at 96 hours (Additional file 1: Figure S1). 
Table 3 Utilization of carbohydrate sources by novel isolate 4A and other known Treponeme species

\begin{tabular}{|c|c|c|c|c|c|}
\hline & Strain $4 A^{* *}$ & T. phagedenist & T. phagedenis (ATCC 27087)** & T. denticola (ATCC 35405)** & T. medium \\
\hline Arabinose & - & - & - & - & - \\
\hline Casein digest & - & $\mathrm{nr}$ & - & - & $\mathrm{nr}$ \\
\hline Cellobiose & - & - & - & - & $\mathrm{nr}$ \\
\hline Fructose & + & + & + & - & + \\
\hline Galactose & - & $d$ & - & - & + \\
\hline Glucose & + & + & + & - & + \\
\hline Lactose & - & + & - & - & - \\
\hline Maltose & + & - & + & - & + \\
\hline Mannitol & + & + & - & - & - \\
\hline Mannose & + & + & + & - & + \\
\hline Pectin & + & $\mathrm{nr}$ & + & + & $\mathrm{nr}$ \\
\hline Ribose & + & $d$ & + & - & + \\
\hline Soluble starch & + & - & + & - & $\mathrm{nr}$ \\
\hline Sucrose & - & - & - & - & + \\
\hline Trehalose & - & $d$ & + & - & + \\
\hline Xylose & - & - & - & - & - \\
\hline
\end{tabular}

$\dagger$ as listed in Bergey's Manual of Systematic Bacteriology $2^{\text {nd }} E D$, Vol 4. $d$ - Different biovars give different results, nr- not reported.

${ }^{* *}$ As determined in this study.

\section{Genomic comparison}

Comparisons of proteins predicted for isolate $4 \mathrm{~A}$ and $T$. phagedenis F0421, whose sequence was obtained from the human microbiome project, made using the RAST server showed a high degree of similarity. At the amino acid level, approximately $86 \%$ of the proteins predicted for $T$. phagedenis F0421 demonstrated $>95 \%$ identity to proteins encoded by genes identified in isolate 4A. Over $50 \%$ of the encoded proteins examined demonstrate $>99.5 \%$ identity (data not shown).

Results from comparisons made using Genome-ToGenome Distance Calculator (GGDC) appear in Table 4. Comparison of genomic contigs from isolate 4A and Treponema phagedenis F0421 using either BLAT or BLAST analysis indicate that isolate $4 \mathrm{~A}$ is $>70 \%$ similar to F0421 and should not be considered a new species. These comparisons along with the global RAST comparison (4A to F0421) are in agreement that the two isolates are highly similar and should most likely be treated as the same species. Results further indicate that isolate $4 \mathrm{~A}$ is $<70 \%$ similar to other fully sequenced Treponema species available in Genbank, including T. succinifaciens, T. azotonutricium, T. primita, T. brennaborense, $T$. denticola, T. paraluiscuniculi, and T. pallidum.

\section{Discussion}

Treponema spirochetes have been found in many species of animals in close association with their host, with distinct species colonizing genitalia, gastrointestinal tracts and oral cavity. Treponema spirochetes can co- exist as harmless commensals (e.g., T. refringens, T. minutum), symbionts of the intestinal tract (e.g., T. bryantii of ruminants, $T$. primitia from termites), pathogens ( $T$. pallidum spp.) or as part of a pathogenic complex of bacteria ( $T$. denticola, $T$. vincentii, and others from the oral cavity) [20,22]. Additionally, several different phylogenetic groups of Treponema species have been isolated or identified in digital dermatitis lesions, with similarities to $T$. denticola, T. phagedenis, T. vincentii, T. medium, and the proposed new species $T$. brennaborense and $T$. pedis [16,23-27]. Four Treponema spirochetes were isolated from DD lesions on an Iowa dairy, and the characterization presented here demonstrates that they are highly similar to the $T$. phagedenis type strain. Despite classification as the same genus, these organisms occupy not just different hosts (bovine vs. human), but also very different anatomical locations (dermis adjacent to heel bulb and dewclaw vs. genitalia). There most likely exists some overlap of microenvironment within these anatomical locations (low oxygen availability, epithelial cell layers, etc.) as both the DD isolates and $T$. phagedenis have similar growth characteristics and nutrient requirements.

Other pathogenic organisms such as Mycobacterium intracellulare, Yersinia species and Bacillus species have identical $16 \mathrm{~s}$ rRNA gene sequences and are highly genetically similar based on DNA-DNA hybridization [28]. However, they exhibit distinct "ecophysiological" properties based on virulence phenotypes or host ranges. Some are distinct species, $Y$. pestis and $Y$. pseduotuberculosis 


\begin{tabular}{|c|c|c|}
\hline Reference Sequencet & $\begin{array}{c}\text { Comparison } \\
\text { Program }\end{array}$ & $\begin{array}{l}\mathrm{DDH} \% \\
\text { estimate }\end{array}$ \\
\hline $\begin{array}{l}\text { Treponema phagedenis F0421* } 2.83 \mathrm{Mb} \text {, } \\
\text { AEFH00000000.1 }\end{array}$ & BLAT & 82.11 \\
\hline $\begin{array}{l}\text { Treponema phagedenis F0421* } 2.83 \mathrm{Mb} \text {, } \\
\text { AEFH000000000.1 }\end{array}$ & NCBI-BLAST & 84.59 \\
\hline Treponema succinifaciens DSM 2489 & $"$ & 52.5 \\
\hline \multicolumn{3}{|l|}{$\begin{array}{l}\text { Complete chromosome, } 2.73 \mathrm{Mb}, \\
\text { NC_015385.1 }\end{array}$} \\
\hline Treponema azotonutricium ZAS 9 & $"$ & 47.15 \\
\hline \multicolumn{3}{|l|}{$\begin{array}{l}\text { Complete chromosome, } 3.85 \text { Mb, } \\
\text { NC_015577.1 }\end{array}$} \\
\hline Treponema primitia ZAS 2 & $"$ & 45.7 \\
\hline \multicolumn{3}{|l|}{$\begin{array}{l}\text { Complete chromosome, } 4.05 \text { Mb, } \\
\text { NC_015578.1 }\end{array}$} \\
\hline Treponema brennaborense DSM 12 & $"$ & 35.64 \\
\hline \multicolumn{3}{|l|}{$\begin{array}{l}\text { Complete chromosome, } 3.05 \text { Mb, } \\
\text { NC_015500.1 }\end{array}$} \\
\hline Treponema denticola ATCC 35405 & $"$ & 29.34 \\
\hline \multicolumn{3}{|l|}{$\begin{array}{l}\text { Complete chromosome, } 2.84 \text { Mb, } \\
\text { NC_002967.9 }\end{array}$} \\
\hline Treponema paraluiscuniculi Cuniculi A & $"$ & 25.82 \\
\hline \multicolumn{3}{|l|}{$\begin{array}{l}\text { Complete chromosome, } 1.13 \text { Mb, } \\
\text { NC_015714.1 }\end{array}$} \\
\hline Treponema pallidum subsp. pallidum SS14 & $"$ & 25.75 \\
\hline $\begin{array}{l}\text { Complete chromosome, } 1.14 \text { Mb, } \\
\text { NC_010741.1 }\end{array}$ & & \\
\hline
\end{tabular}

†All comparisons used 60 Contigs assembled for Isolate $4 \mathrm{~A}$ as Query and report results using Formula 2 (Identities/HSP length).

**Regression based. DNA-DNA Hybridization (DDH\%) estimates $\leq 70 \%$ indicate organisms compared represent different species. Estimates $>70 \%$ indicate organisms represent same species.

*277 Contigs for Treponema phagedenis F0412 were used as reference sequence.

for example, while others are merely different serovars within the species, such as $M$. intracellulare. Some pathogens are separated from other genetically identical species by acquisition of a plasmid conferring pathogenic properties. Evaluation of the draft contigs of T. phagedenis and the DD isolates do not give any indication of acquisition of a plasmid that would have conferred the expansion of host range or conversion into a more virulent organism.

These studies herein led us to develop a growth medium reduced in complexity so that the individual nutrients and growth factors of previously isolated spirochetes could be further evaluated. While the list of components appear similar to fastidious anaerobe broth used by many groups $[17,29]$, the quantities of several components are greatly reduced. Systematic studies on essential nutrients and environmental growth factors of the nonpallidum treponemes are scarce [22] and consist of a few incomplete lists in such reference texts as Bergey's Manual of Systematic Bacteriology and The Prokaryotes $[18,21]$. A recently published report showed that isolate $1 \mathrm{~A}$ achieved $\log$ phase growth in 3 to 5 days of culture in a rich media similar to fastidious anaerobe broth [29] consistent with our results in both media types.

We have defined temperature tolerances, $\mathrm{pH}$ tolerances and essential growth requirements (serum and VFAs) of isolate 4A. It was very interesting that an organism isolated from the hoof of a cow was tolerant to and preferred higher temperatures (up to $40^{\circ} \mathrm{C}$ ). The hoof temperature of a dairy cow ranges from 21 to $23^{\circ} \mathrm{C}$ [30]. The hoof surface temperature was found to increase in cases of DD, sole ulcers, or other hoof diseases [30], and thus could create a more favorable environment for treponemal growth.

Further insight into the Iowa DD isolates physiology was sought by evaluation of substrate utilization and enzymatic activity of the treponeme isolates. By understanding growth requirements and nutritional capabilities of these isolates, we can begin to piece together the microenvironment necessary for optimal survival and growth of the treponemes. As in the case of human periodontal disease, one bacterial colonizer may provide the nutritional substrates for secondary colonizers and tissue destructive bacteria [31]. There were little differences between $T$. phagedenis and the DD isolates on the basis of enzymatic activity or substrate utilization, mainly regarding mannitol and trehalose. While there were slight differences in enzymatic profiles, these are generally not sufficient for the separation into different species. For example, T. phagedenis biovar Reiter is able to hydrolyze esculin but biovar Kazan does not [18]. As the complete sequences of both $T$. phagedenis and these DD isolates become available, these small biochemical differences may be explained by alterations in the genome consistent with host adaptation.

Past studies have evaluated the similarity of DD Treponema isolates based on sequencing of $16 \mathrm{~S}$ ribosomal regions, 16-23S intergenic spacer regions or conserved flagellin genes (i.e., flaB2). Previously published work has shown that the T. phagedenis-like isolates 9-3301, 7-2009, 2-1498 from California, and 1A and 4A from Iowa, have $>99 \%$ identical 16S-23S rRNA gene sequence and intergenic spacer regions clustered into the same phylotype based on product length polymorphisms [10]. Although a completed genome for any $T$. phagedenis isolate is not available, comparison of assembled contigs for isolate 4A revealed a high degree of similarity throughout the genome. Differences in the number of genes identified (3251 in isolate 4A and 2799 genes in F0421) most likely reflect a difference in sequencing coverage and completeness of the resulting contigs. Performance of in silico DDH using isolate 4A and F0421 
further supports classification of the bovine lesion isolates as T. phagedenis.

\section{Conclusion}

These results indicate that a similar bacterium has been independently isolated in several geographical locations (i.e., IA, CA, Sweden, UK, Germany) but also from bovine and human hosts. However, even with the high degree of genomic, structural, and physiological similarity between isolates, variation exists with regard to immune reactivity and host recognition of differing surface antigens $[13,32]$. In conclusion, the bovine isolates are by all tests nearly identical to $T$. phagedenis biovar Kazan and published sequences of T. phagedenis reference tp_F0421 and as such do not represent novel species. The descriptions of $T$. phagedenis should be expanded to describe the organism as human genitalia commensal and putative pathogen of bovine digit.

\section{Methods}

Bacterial cultures

Type species Treponema phagedenis bivar Kazan (ATCC 27087), Treponema vincentii LA (ATCC 35580) and Treponema denticola (ATCC 35405) were purchased from the American Type Culture Collection (ATCC, Manassas, VA). T. phagedenis-like ioslates 1A, 3A, 4A and $5 \mathrm{~B}$ were isolated from lesions on Iowa dairy cattle as previously described [14].

\section{Culture media and conditions}

Treponeme isolates were cultured in two different media for these studies: oral Treponeme isolation (OTI) broth and basal minimal media with volatile fatty acids (BMV). Media were prepared under $100 \%$ nitrogen as previously described [14] and formulas are listed (Table 5). As needed, $15 \mathrm{~g}$ per L noble agar (DIFCO) and 5\% bovine blood were added. BMV was formulated to grow spirochetes in a minimal nutrient medium and facilitate metabolic end product analyses. Cultures were adapted to BMV for at least five passages before being utilized in analyses. All studies were conducted using cultures under anaerobic atmosphere conditions (5\% hydrogen, $5 \%$ carbon dioxide, $90 \%$ nitrogen) in chemically reduced media. Optimal $\mathrm{pH}$ for growth of isolate $4 \mathrm{~A}$ was determined by using OTI and adjusting the $\mathrm{pH}$ using $1 \mathrm{~N}$ hydrochloric acid or $1 \mathrm{~N}$ sodium hydroxide. Growth substrates were identified by adding different carbohydrate sources to BMV media (Table 5). Bacterial density was measured using a spectrophotometer and related to bacterial cell numbers as determined from direct cell counts using dark field microscopy.
Table 5 Composition of oral Treponema isolation (OTI) and basal minimal media with VFA (BMV) media used in these studies

\begin{tabular}{|c|c|c|}
\hline Component & OTI & $\overline{B M V}$ \\
\hline Polypeptone & $5.0 \mathrm{~g}$ & $5.0 \mathrm{~g}$ \\
\hline Heart Infusion Broth & $5.0 \mathrm{~g}$ & $5.0 \mathrm{~g}$ \\
\hline Yeast Extract (YE) & $5.0 \mathrm{~g}$ & $1.0 \mathrm{~g}$ \\
\hline Glucose & $0.8 \mathrm{~g}$ & $\dagger$ \\
\hline Pectin & $0.8 \mathrm{~g}$ & $\dagger$ \\
\hline Soluble Starch & $0.8 \mathrm{~g}$ & $\dagger$ \\
\hline Arabinose & & $\dagger$ \\
\hline Casein Digest & & $\dagger$ \\
\hline Cellobiose & & $\dagger$ \\
\hline Fructose & & $\dagger$ \\
\hline Mannitol & & $\dagger$ \\
\hline Galactose & & $\dagger$ \\
\hline Lactose & & $\dagger$ \\
\hline Trehalose & & $\dagger$ \\
\hline Mannose & & $\dagger$ \\
\hline Sucrose & $0.8 \mathrm{~g}$ & $\dagger$ \\
\hline Maltose & $0.8 \mathrm{~g}$ & $\dagger$ \\
\hline Ribose & $0.8 \mathrm{~g}$ & $\dagger$ \\
\hline Xylose & $0.8 \mathrm{~g}$ & $\dagger$ \\
\hline Sodium Pyruvate & $0.8 \mathrm{~g}$ & $\dagger$ \\
\hline $\mathrm{K}_{2} \mathrm{HPO}_{4}$ & $2.0 \mathrm{~g}$ & $2.0 \mathrm{~g}$ \\
\hline $\mathrm{NaCl}$ & $5.0 \mathrm{~g}$ & $5.0 \mathrm{~g}$ \\
\hline $\mathrm{MgSO}_{4}$ & $0.1 \mathrm{~g}$ & $0.1 \mathrm{~g}$ \\
\hline Cysteine- $\mathrm{HCl}$ & $0.68 \mathrm{~g}$ & $1.0 \mathrm{~g}$ \\
\hline DI Water & $500 \mathrm{ml}$ & $822 \mathrm{ml}$ \\
\hline Resazurin (0.1\%) & $1.0 \mathrm{ml}$ & $1.0 \mathrm{ml}$ \\
\hline Rumen Fluid & $500 \mathrm{ml}$ & \\
\hline VFA Solution** & & $10 \mathrm{ml}$ \\
\hline Bovine Serum§ & $1 \mathrm{ml} / 10 \mathrm{ml}$ & $1 \mathrm{ml} / 10 \mathrm{ml}$ \\
\hline \multicolumn{3}{|c|}{$\begin{array}{l}- \text { To test carbohydrate substrates } 0.5 \mathrm{ml} \text { of a } 10 \% \text { solution of each was } \\
\text { added to } 8.5 \mathrm{ml} \text { media just before reduction and inoculation. } \\
\text { **VFA Solution consisted of } 0.5 \mathrm{ml} \text { each of isovaleric, isobutyric, n-valeric, } \\
\text { DL-a-methylbutyric acid in } 100 \mathrm{ml} 0.1 \mathrm{~N} \mathrm{NaOH} \text {. } \\
\text { § Final concentration }=10 \% \text { Bovine serum, added to } 8.5 \mathrm{ml} \text { medium just } \\
\text { before reduction and inoculation. }\end{array}$} \\
\hline
\end{tabular}

\section{Electron microscopy}

Actively dividing cells of the DD isolates were grown in OTI and were prepared for transmission electron microscopy. Cells were collected by centrifugation $(10,000 \times \mathrm{g}$, 10 minutes) and washed twice in cold $10 \mathrm{mM}$ phosphate buffered saline (pH 7.4, PBS) with final suspension in distilled water. Samples were negatively stained with an equal volume of $2 \%$ phosphotungstic acid $(\mathrm{pH} 7.0)$ and mounted on a formvar/carbon reinforced 200-mesh copper grid. Grids were examined at $80 \mathrm{kV}$ under a FEI Tecnai G2 electron microscope equipped with AMT camera. 


\section{Metabolic characterization}

Bacterial cells from log phase culture grown in BMV with glucose and $10 \%$ bovine serum were collected by centrifugation $(10,000 \times \mathrm{g}, 10$ minutes), washed twice in isotonic saline and resuspended in isotonic saline to a density of 5-6 using McFarland standard. The API-ZYM test (bioMerieux) was performed per manufacturer's instructions. The enzyme $\beta$-glucosidase ( $0.2 \mathrm{~g} / \mathrm{L}$, Sigma) was used as an internal control.

\section{Volatile fatty acid quantification}

To determine volatile fatty acid production, $9.9 \mathrm{~mL}$ of BMV medium with glucose and $10 \%$ bovine serum was inoculated with $100 \mu \mathrm{l}$ of $1 \times 10^{8}$ growing bacterial cells/ $\mathrm{ml}$ and incubated at $37^{\circ} \mathrm{C}$ for $72-96$ hrs. The culture was then centrifuged to remove cellular material and the supernatant prepared for gas-phase liquid chromatography as previously described [33-35]. Uninoculated medium was used as a control.

\section{Hydrogen sulfide production}

$100 \mu \mathrm{l}$ containing $1 \times 10^{8}$ bacterial cells $/ \mathrm{ml}$ from $\log$ phase cultures were inoculated into $9.9 \mathrm{ml}$ BMV and cultured for 72 hours. Hydrogen sulfide was assayed by using the lead acetate test as previously described [36].

\section{DNA sequencing and analysis}

DNA from isolate 4A was extracted from $100 \mathrm{~mL}$ growing broth cultures using DNeasy Blood and Tissue Kit (Qiagen, Valencia, CA) as per manufacturer's instructions. Sequencing reactions were based upon Roche FLX-Titanium and Titanium + chemistry (Roche/454 Life Sciences, Branford, CT 06405; www.454.com) as well as Illumina chemistry (Illumina, Inc., San Diego, CA 92122; www.illumina.com). Genomic DNA was processed according to manufacturer's instructions for preparation of DNA libraries. Whole genome random libraries were prepared and sequenced using the Illumina HiSeq 2000 and a Roche GS-FLX + instrument. In addition, genomic DNA was used to prepare paired-end libraries of $2 \mathrm{~Kb}$ and $8 \mathrm{~Kb}$ according to Roche protocols and was sequenced using the Roche GS-FLX + instrument and Titanium sequencing chemistries. Sequencing data from each of the methodologies was used to perform a de novo assembly using both the MIRA assembler [37] and the Roche gsAssembler (Newbler) version 2.6, (Roche/454 Life Sciences, Branford, CT 06405, USA; www.454.com) Mauve Genome Alignment software was employed to compare assemblies and optimize the resulting de novo assembly. The draft genome assembly consisted of 42 contigs in 14 scaffolds and a total of 3,027,773 bp assembled (Newbler) from a combined coverage of greater than $90 \times$. This Whole Genome Shotgun project has been deposited at DDBJ/EMBL/
GenBank under the accession AQCF00000000. The version described in this paper is the first version, AQCF01000000.

Assembled contigs for 4A and for Treponema phagedenis F0421 (277 contigs, http://www.ncbi.nlm.nih.gov/Traces/ wgs/?val=AEFH01; Accession: PRJNA47285ID: 47285, Accession: PRJNA62291ID: 62291, AEFH00000000.1) from the human microbiome project were submitted to the National Microbial Pathogen Data Resource (NMPDR), SEED-based, Rapid Annotation using Subsystems Technology (RAST) server [38] for annotation and comparison. Isolate 4A was chosen as the reference for RAST comparison purposes, as the genome assembly was in fewer total contigs. A total of 3251 genes were identified in isolate 4A and 2799 genes in F0421. Proteins predicted from the annotated sequence were examined at various levels of percent amino acid identity.

Assembled contigs for 4A were submitted for comparison using the Genome-To-Genome Distance Calculator (GGDC) (http://ggdc.gbdp.org/) [39].

Comparison of isolate 4A and Treponema phagedenis F0421 genomes was additionally performed using BlastLike Alignment Tool (BLAT) [40] because it corresponds better to actual DNA-DNA hybridization (DDH) comparisons than do comparisons performed using BLAST. For genomes that are not closed, (i.e. a file of assembly contigs such as is the case for both $4 \mathrm{~A}$ and F0421), only Formula 2 results should be relied upon for making determinations [41]. Isolate $4 \mathrm{~A}$ was also compared to at least one representative of other Treponema species available in Genbank for a total of 8 comparisons. Since only one genome was closed in these subsequent analyses, the comparisons were based on Basic Local Alignment Search Tool (BLAST) results. DDHbased speciation of bacterial isolates is based on a limit of $70 \%$ similarity in order to make a determination of a new species. Genomes $\leq 70 \%$ similar should be considered different species while genomes $>70 \%$ similar indicate they should not be considered a new species [41].

\section{Additional file}

Additional file 1: Figure S1. Comparison of growth rate for isolate $4 \mathrm{~A}$ in OTI and BMV. After 5 sequential passages in either OTI or BMV, $1 \times 10^{7}$ mid-log phase cells were inoculated in to $10 \mathrm{ml} \mathrm{OTI} \mathrm{or} \mathrm{BMV} \mathrm{and} \mathrm{absorb-}$ ance measured over time. Results are representative of 3 independent experiments, and error bars indicate standard error of the mean.

\section{Competing interest}

The authors declare they have no competing interests.

\section{Authors' contributions}

$M K H, R L Z$ conceived the study, designed and inititated biochemical and biological experimental work. JHWW completed experimental biochemical and biological work, prepared manuscript for publication. RLZ, DPA, DOB designed, implemented and performed sequencing, cloning, and genomic analysis experiments. TBS provided critical insight and guidance for research 
and manuscript preparation. All authors contributed to, read and approved the final manuscript.

\section{Acknowledgements}

We would like to thank Richard Hornsby for exceptional technical support in all phases of this study, Lea Ann Hobbs for assistance in genomic sequencing, Ami Frank for data collection, Deb Lebo for VFA analysis by mass spectroscopy, and Judith Stasko for her work in capturing the EM images.

Mention of trade names or commercial products in this article is solely for providing specific information and does not imply recommendation or endorsement by the U.S. Department of Agriculture. USDA is an equal opportunity provider and employer.

\section{Author details}

${ }^{1}$ Infectious Bacterial Diseases Research Unit, National Animal Disease Center Ames, lowa 50010, USA. ${ }^{2}$ Food Safety and Enteric Pathogens Research Unit, National Animal Disease Center, Ames, lowa 50010, USA. ${ }^{3}$ Mailing address: USDA, ARS, National Animal Disease Center, 1920 N. Dayton Ave, P.O. Box 70, Ames, IA 50010, USA.

Received: 10 September 2013 Accepted: 29 November 2013 Published: 5 December 2013

\section{References}

1. Brown CC, Kilgo PD, Jacobsen KL: Prevalence of papillomatous digital dermatitis among culled adult cattle in the southeastern United States. Am J Vet Res 2000, 61(8):928-930.

2. Cha E, Hertl JA, Bar D, Grohn YT: The cost of different types of lameness in dairy cows calculated by dynamic programming. Prev Vet Med 2010, 97(1):1-8.

3. Shearer JK, Van Amstel S: Lamness in Dairy Cattle. In Kentucky Dairy Conference. Lexington, KY; 2000:1-12. http://www.healthyhooves.com/ pdffiles/dr\%20shearer.pdf accessed 12-3-13.

4. Fidler AP, Alley ML, Smith GW: Evaluation of a Serpens species bacterin for treatment of digital dermatitis in dairy cattle. Res Vet Sci 2012, 93(3):1258-1260

5. Ertze RA, Read DH, Hird DW, Berry SL: Field evaluation of prophylactic and therapeutic effects of a vaccine against (Papillomatous) digital dermatitis in dairy cattle on two California dairies. Bovine Practitioner 2006, 40:76-82.

6. Berry SL, Read DH, Famula TR, Mongini A, Dopfer D: Long-term observations on the dynamics of bovine digital dermatitis lesions on a California dairy after topical treatment with lincomycin $\mathrm{HCl}$. Vet J 2012, 193(6):654-658.

7. Rollin BE: An ethicist's commentary on trimming of lame dairy cattle. The Canadian veterinary journal La revue veterinaire canadienne 2005, 46(6):483.

8. Moter A, Leist G, Rudolph R, Schrank K, Choi BK, Wagner M, Gobel UB: Fluorescence in situ hybridization shows spatial distribution of as yet uncultured treponemes in biopsies from digital dermatitis lesions. Microbiology 1998, 144(9):2459-2467.

9. Cruz CE, Pescador CA, Nakajima Y, Driemeier D: Immunopathological investigations on bovine digital epidermitis. Vet Rec 2005, 157(26):834-840.

10. Stamm LV, Bergen HL, Walker RL: Molecular typing of papillomatous digital dermatitis-associated Treponema isolates based on analysis of 16S-23S ribosomal DNA intergenic spacer regions. J Clin Microbiol 2002, 40(9):3463-3469.

11. Walker RL, Read DH, Loretz KJ, Nordhausen RW: Spirochetes isolated from dairy cattle with papillomatous digital dermatitis and interdigital dermatitis. Vet Microbio/ 1995, 47(3-4):343-355.

12. Demirkan I, Williams HF, Dhawi A, Carter SD, Winstanley C, Bruce KD, Hart CA: Characterization of a spirochaete isolated from a case of bovine digital dermatitis. J Appl Microbiol 2006, 101(4):948-955.

13. Elliott MK, Alt DP: Bovine immune response to papillomatous digital dermatitis (PDD)-associated spirochetes is skewed in isolate reactivity and subclass elicitation. Vet Immunol Immunopathol 2009, 130(3-4):256-261.

14. Trott DJ, Moeller MR, Zuerner RL, Goff JP, Waters WR, Alt DP, Walker RL, Wannemuehler MJ: Characterization of Treponema phagedenis-like spirochetes isolated from papillomatous digital dermatitis lesions in dairy cattle. J Clin Microbiol 2003, 41(6):2522-2529.
15. Walker RL, Read DH, Loretz KJ, Hird DW, Berry SL: Humoral response of dairy cattle to spirochetes isolated from papillomatous digital dermatitis lesions. Am J Vet Res 1997, 58(7):744-748.

16. Evans NJ, Brown JM, Demirkan I, Murray RD, Vink WD, Blowey RW, Hart CA Carter SD: Three unique groups of spirochetes isolated from digital dermatitis lesions in UK cattle. Vet Microbiol 2008, 130(1-2):141-150.

17. Pringle $M$, Bergsten $C$, Fernstrom LL, Hook H, Johansson KE: Isolation and characterization of Treponema phagedenis-like spirochetes from digital dermatitis lesions in Swedish dairy cattle. Acta Vet Scand 2008, 50:40.

18. Paster BJ: PhylumXV. Spirochaetes. In Bergey's Manual of Systematic Bacteriology, Volume 4. 2nd edition. Edited by Krieg NR, Staley JT, Brown DR, Hedlund BP, Paster BJ, Ward NL, Ludwig W, Whitman WB. New York, New York: Springer; 2011.

19. Wyss C, Moter A, Choi BK, Dewhirst FE, Xue Y, Schupbach P, Gobel UB, Paster BJ, Guggenheim B: Treponema putidum sp. nov., a medium-sized proteolytic spirochaete isolated from lesions of human periodontitis and acute necrotizing ulcerative gingivitis. Int J Syst Evol Microbiol 2004, 54(Pt 4):1117-1122.

20. Evans NJ, Brown JM, Murray RD, Getty B, Birtles RJ, Hart CA, Carter SD: Characterization of novel bovine gastrointestinal tract Treponema isolates and comparison with bovine digital dermatitis treponemes. Appl Environ Microbiol 2011, 77(1):138-147.

21. The Prokaryotes A handbook on the biology of bacteria: vol. 7: Proteobacteria: Delta and Epsilon Subclasses. Deeply Rooting Bacteria. 3rd edition. New York, New York: Springer; 2006

22. Norris SJ, Paster BJ, Moter A, Gobel UB: The Genus Treponema. In Prokaryotes, Volume 7. 3rd edition. Edited by Dworkin M, Falkow S, Rosenberg E, Schleifer K-H, Stackebrandt E. New York, New York: Springer; 2006:211-234.

23. Choi BK, Nattermann H, Grund S, Haider W, Gobel UB: Spirochetes from digital dermatitis lesions in cattle are closely related to treponemes associated with human periodontitis. Int J Syst Bacteriol 1997, 47(1):175-181.

24. Edwards AM, Dymock D, Woodward MJ, Jenkinson HF: Genetic relatedness and phenotypic characteristics of Treponema associated with human periodontal tissues and ruminant foot disease. Microbiology 2003, 149(5):1083-1093.

25. Evans NJ, Brown JM, Demirkan I, Murray RD, Birtles RJ, Hart CA, Carter SD: Treponema pedis sp. nov., a spirochaete isolated from bovine digital dermatitis lesions. Int J Syst Evol Microbiol 2009, 59(5):987-991.

26. Klitgaard K, Boye M, Capion N, Jensen TK: Evidence of multiple Treponema phylotypes involved in bovine digital dermatitis as shown by $16 \mathrm{~S}$ rRNA gene analysis and fluorescence in situ hybridization. J Clin Microbio/ 2008, 46(9):3012-3020.

27. Schrank K, Choi BK, Grund S, Moter A, Heuner K, Nattermann H, Gobel UB: Treponema brennaborense sp. nov., a novel spirochaete isolated from a dairy cow suffering from digital dermatitis. Int J Syst Bacteriol 1999, 49(1):43-50.

28. Jaspers E, Overmann J: Ecological significance of microdiversity: identical 16S rRNA gene sequences can be found in bacteria with highly divergent genomes and ecophysiologies. Appl Environ Microbiol 2004, 70(8):4831-4839.

29. Dopfer D, Anklam K, Mikheil D, Ladell P: Growth curves and morphology of three Treponema subtypes isolated from digital dermatitis in cattle. Vet J 2012, 193(3):685-689.

30. Stokes JE, Leach KA, Main DC, Whay HR: An investigation into the use of infrared thermography (IRT) as a rapid diagnostic tool for foot lesions in dairy cattle. Vet J 2012, 193(3):674-678.

31. Kuramitsu HK, He X, Lux R, Anderson MH, Shi W: Interspecies interactions within oral microbial communities. Microbiol Mol Biol Rev 2007, 71(4):653-670.

32. Elliott MK, Alt DP, Zuerner RL: Lesion formation and antibody response induced by papillomatous digital dermatitis-associated spirochetes in a murine abscess model. Infect Immun 2007, 75(9):4400-4408.

33. Salanitro JP, Muirhead PA: Quantitative method for the gas chromatographic analysis of short-chain monocarboxylic and dicarboxylic acids in fermentation media. App/ Microbiol 1975, 29(3):374-381.

34. Stanton TB, Lebo DF: Treponema hyodysenteriae growth under various culture conditions. Vet Microbiol 1988, 18(2):177-190.

35. Trott DJ, Stanton TB, Jensen NS, Hampson DJ: Phenotypic characteristics of Serpulina pilosicoli the agent of intestinal spirochaetosis. FEMS Microbiol Lett 1996, 142(2-3):209-214. 
36. Clarke PH: Hydrogen sulphide production by bacteria. J Gen Microbiol 1953, 8(3):397-407.

37. Chevreux B, Wetter T, Suhai S: Genome Sequence Assembly Using Trace Signals and Additional Sequence Information. In Computer Science and Biology: Proceedings of the German Conference on Bioinformatics (GCB) 99. 1999:45-56.

38. Aziz RK, Bartels D, Best AA, DeJongh M, Disz T, Edwards RA, Formsma K, Gerdes S, Glass EM, Kubal M, et al: The RAST Server: rapid annotations using subsystems technology. BMC Genomics 2008, 9:75.

39. Auch AF, von Jan M, Klenk HP, Goker M: Digital DNA-DNA hybridization for microbial species delineation by means of genome-to-genome sequence comparison. Standards in Genomic Sci 2010, 2(1):117-134.

40. Kent WJ: BLAT-the BLAST-like alignment tool. Genome Res 2002, 12(4):656-664.

41. Goris J, Konstantinidis KT, Klappenbach JA, Coenye T, Vandamme P, Tiedje JM: DNA-DNA hybridization values and their relationship to wholegenome sequence similarities. Int J Syst Evol Microbiol 2007, 57(1):81-91.

doi:10.1186/1471-2180-13-280

Cite this article as: Wilson-Welder et al: Biochemical and molecular characterization of Treponema phagedenis-like spirochetes isolated from a bovine digital dermatitis lesion. BMC Microbiology 2013 13:280.

\section{Submit your next manuscript to BioMed Central and take full advantage of:}

- Convenient online submission

- Thorough peer review

- No space constraints or color figure charges

- Immediate publication on acceptance

- Inclusion in PubMed, CAS, Scopus and Google Scholar

- Research which is freely available for redistribution 